О. О. Ханюков, Є. Д. Єгудіна, М. Г. Гетман, О. С. Калашникова

ДЗ “Дніпропетровська медична академія МОЗ України”, м. Дніпро

\title{
ІМПЛЕМЕНТАЦІЯ СИМУЛЯЦІЙНОГО ТРЕНІНГУ НАДАННЯ НЕВІДКЛАДНОЇ ДОПОМОГИ ДЛЯ СТУДЕНТІВ 6 КУРСУ ПРИ ВИВЧЕННІ ДИСЦИПЛІНИ “ВНУТРІШНЯ МЕДИЦИНА” (ОГЛЯД ЛІТЕРАТУРИ ТА ВЛАСНИЙ ДОСВІД)
}

\author{
O. O. Khaniukov, Ye. D. Yehudina, M. H. Hetman, O. S. Kalashnykova \\ Dnipropterovsk Medical Academy, Dnipro \\ IMPLEMENTATION OF THE SIMULATIVE TRAINING TO PROVIDE \\ EMERGENCY AID FOR 6-YEAR STUDENTS IN THE INTERNAL \\ MEDICINE DISCIPLINE STUDY (LITERATURE REVIEW AND OWN \\ EXPERIENCE)
}

\begin{abstract}
Мета роботи - аналіз, узагальнення існуючих точок зору в системі освіти, які торкаються питання про необхідність, ефективність та особливості використання симуляційних програм навчання студентів-медиків.

Основна частина. Проведено огляд сучасної літератури по впровадженню симуляційних методів навчання в медичній освіті. Симуляційне навчання $є$ одним з ефективних способів навчитися керувати помилками. Симуляційне навчання дозволяє навчатися працювати відповідно до сучасних алгоритмів діагностики та надання невідкладної допомоги, виробити командну взаємодію та координацію, підвищити рівень виконання складних медичних маніпуляцій та оцінити ефективність власних дій. Зокрема, в ДЗ “ДМА МОЗ України” на кафедрі внутрішньої медицини 3 розроблена методика імітаційного навчання із залученням співробітників ВНЗ в якості стандартизованих пацієнтів для моделювання клінічних ситуацій диференціації та надання допомоги при різних невідкладних станах.

Висновки. На наш погляд, дана імплементація симуляційного тренінгу є цінним інструментом вдосконалення професійних навичок студентів медичних вузів. Елементи даної методики застосовні на різних етапах освітньої діяльності: не тільки при відпрацюванні навичок невідкладної допомоги, а також при проведенні підсумкової атестації студентів 6 курсу.
\end{abstract}

Ключові слова: навчання; студенти 6 курсу; медична освіта; симуляція; стандартизований пацієнт.

The aim of the work - to analyze, generalize existing points of view in the education system, which affect the issue of necessity, effectiveness and features of the simulation programs use for medical students.

The main body. An overview of modern literature on the implementation of simulation methods in medical education. Simulation training is one of the effective ways to learn how to manage errors. Simulation training allows to learn how to work in accordance with modern algorithms for diagnosis and emergency care, to develop team interaction and coordination, to increase the level of implementation of complex medical manipulations and to evaluate the effectiveness of their own actions. In particular, at the Internal Medicine Department No. 3 of Dnipropetrovsk Medical Academy a method of simulation training is developed involving university staff as "standardized patients” for modeling clinical situations of differentiation and assistance in various urgent states.

Conclusions. In our view, this implementation of the simulation training is a valuable tool for improving the professional skills of medical students. Elements of this technique are applicable at different stages of educational activity: not only in the development of skills in emergency care, but also during the final certification of the 6th year students.

Key words: training; 6-year students; medical education; simulation; standardized patient.

Вступ. Медична освіта зазнає чималих змін і вдосконалюється у всьому світі. Одна з головних причин - поліпшення безпеки пацієнтів. За оцінками Інституту медицини США, медичні помилки призводять до погіршення стану 3 \% пацієнтів і $€$ причиною від 44000 до 98000 смертей на рік [1].
T. A. Brennan та спіавтори провели аналіз гарвардської медичної практики, розглянули понад 30000 випадково відібраних історій хвороб у медичних центрах Нью-Йорка в рамках міждисциплінарного дослідження медичних травм і судових процесів внаслідок недбалості лікарів. Було виявлено,

( О. О. Ханюков, Є. Д. Єгудіна, М. Г. Гетман, О. С. Калашникова 
що ятрогенні ураження пацієнтів сталися в 3,7 \% випадків госпіталізації, 27,6 \% з яких були викликані неохайністю та недбалістю, що призвело до смерті 13,6 \% пацієнтів [2]. Медичні помилки також сприяють підвищенню вартості медичної допомоги в усьому світі. Щорічні витрати, пов'язані з медичними помилками на 700 ліжко-місць, були оцінені в 5,6 млн доларів [3].

Паралельні зміни в системі медичної допомоги третинного рівня, яка традиційно є місцем навчання студента-медика на клінічних кафедрах, також вплинули на медичне навчання. Оскільки лікарні все частіше стають місцем короткочасного перебування пацієнта з акцентом на одноденні процедури та раннє виписування пацієнта із стаціонару, лише важкохворі залишаються на більш тривалий час. Таким чином, студенти-медики не мають доступу до повного спектра навчального досвіду, маючи менше можливостей спостерігати й оцінювати пацієнтів з широким спектром захворювань та характерних для них симптомів і синдромів.

Зважаючи на вищесказане, в даний час виникає необхідність технологічної трансформації медичної освіти. Зміни методик навчання студентів привели до інноваційних медичних навчальних програм. Нові навчальні плани підкреслюють важливість знання багатьох клінічних навичок студентів 6 курсу. Це, перш за все, вміння вести себе в критичній ситуації, надання пацієнтам невідкладної допомоги, набуття практичних навичок, а не просто теоретичних знань [4].

Зависокі сучасні вимоги до засвоєння практичних навичок учнями-медиками, необхідність актуалізації навчального матеріалу та наближення освітнього оточення до практичної медицини роблять віртуальні технології у медичній освіті ключовим напрямком розвитку вищої медичної школи. Загальновизнано, що практичні навички є важливим результатом навчання. Набуття відповідних клінічних навичок $є$ ключем до навчання студентів-медиків, але іноді молоді лікарі, що озброєні теоретичними знаннями, мають проблеми з визначенням тактики своєї поведінки в деяких практичних ситуаціях [5].

Більшість вищих навчальних медичних закладів України змінили свої навчальні плани та прийняли такі освітні стратегії, як симуляційний тренінг, для вирішення основної проблеми медичних студентів - застосування теоретичних знань для практичного менеджменту пацієнтами.
Мета роботи - аналіз, узагальнення існуючих точок зору в системі освіти, які торкаються питання про необхідність, ефективність та особливості використання симуляційних програм навчання студентів-медиків.

Основна частина. Проведено огляд сучасної літератури по впровадженню симуляційних методів навчання в медичній освіті. Був проведений пошук літератури в базі даних MEDLINE/PubMed з відповідних статей, опублікованих у період з 1990 по 2017 рік. Основними умовами пошуку були такі ключові слова: симуляційні методики, стандартизований пацієнт, медична освіта, клінічні навички, невідкладні стани. Статті були розглянуті, якщо вони вважалися релевантними для пошуку. Також представлений власний досвід по впровадженню симуляційного тренінгу для студентів 6 курсу при вивченні дисципліни “Внутрішня медицина”.

Авіаційна і аерокосмічна промисловість вже багато років використовує симуляцію як навчальний інструмент. Симулятори широко використовуються в освіті та навчанні в різних професіях та дисциплінах високого ризику, включаючи військові, комерційні авіакомпанії, атомні електростанції, бізнес та медицину [6]. Існує безліч прикладів реформування навчальних медичних програм, які включають у себе вдосконалення навчально-методичних навичок, використання тренажерів та створення симуляційних центрів [7].

Історія симуляційних технологій починається 3 XVIII ст., коли у Франції був створений перший симулятор породіллі [8]. Слідом за Францією симулятори почали розробляти в Англії, Японії, Нiмеччині та інших країнах. В середині XX століття в Норвегії був розроблений перший манекен для відпрацювання серцево-легеневої реанімації [9]. Відтоді всі країни почали активно розробляти та застосовувати симулятори для тренування широкого спектра практичних медичних навичок $[10,11]$.

Відомо, що для успішного лікаря необхідно мати великий практичний досвід. Для розробки практичних навичок та умінь створюються симуляційно-атестаційні центри, в яких за допомогою симуляційних технологій проводяться навчання, тестування та атестація студентів, ординаторів та лікарів [12]. Вимоги до підвищення якості професійної підготовки фахівців з медичною освітою змушують шукати раціональні рішення, підлагоджуючи систему їх навчання. Закономірно, що одним із головних напрямків у сфері вищої медичної 
освіти є необхідність значного посилення практичного аспекту підготовки майбутніх лікарів при збереженні належного рівня теоретичних знань. Використання симуляторів, манекенів, фантомів дозволяє багатократно виконувати певні вправи та дії при забезпеченні тимчасових, детальних професійних інструкцій під час роботи [13].

Медичну освіту на сучасному етапі неможливо уявити без застосування симуляційних технологій. У даний час при навчанні спеціалістів у медичних вузах України та в практичній медицині, а також у світовій практиці, бачимо ряд проблем, що мають ключове значення і які визначають якість надання медичної допомоги населенню: все більше обмежується можливість навчання при безпосередній роботі з пацієнтами.

Симуляційне навчання є одним з ефективних способів навчитися керувати помилками [14]. Симуляція (від лат. simulatio - вдавання) - це мистецтво імітувати реальність, хибне зображення хвороби або окремих іï симптомів, при якому той, хто навчається, діє у відповідній обстановці і знає про це [15]. При цьому певний набір умов створюється штучно, щоб вивчити те, що можливо в реальному житті. Симуляція в медичній освіті - це сучасна технологія навчання, оцінювання практичних навичок, умінь та знань, основана на імітаціях клінічної ситуації або окремо взятої фізіологічної системи, з можливим використанням механічних, електронних або комп’ютерних моделей [16]. Таким чином, освітні цілі досягаються за допомогою експериментального навчання [17].

3 іншого боку, симуляційна медична освіта може бути визначена як будь-яка освітня діяльність, яка використовує симулятивних асистентів для розіграшу клінічних сценаріїв, що служить альтернативою реальному пацієнту [18].

Ціль симуляції - це вдосконалення майстерності студентів, закріплення і поглиблення знань та умінь, отриманих у процесі професійного навчання, стимулювання творчого росту студентів [13].

Завдання симуляції:

1. Підвищення інтересу студентів до своєї спеціальності та її соціальної значимості.

2. Розвиток можливостей самостійно й ефективно вирішити проблеми у сфері професійної діяльності.

3. Перевірка професійної готовності майбутнього спеціаліста до самостійної трудової діяльності.

На відміну від звичайних умов навчальної кімнати, симулятор дозволяє студенту думати в екстремальних ситуаціях, спонтанно й активно, а не пасивно запам'ятовувати інформацію. При симуляційному навчанні головним є набуття необхідних практичних навичок та теоретичних знань, не наносячи шкоди здоров’ю людини, при збереженні повноти та реалістичності моделювання [19]. Симуляційне навчання дозволяє навчатися працювати відповідно до сучасних алгоритмів діагностики та надання невідкладної допомоги, виробити командну взаємодію та координацію, підвищити рівень виконання складних медичних маніпуляцій та оцінити ефективність власних дій. Для цього необхідно знати основи патофізіології, клініки й діагностики захворювань різних органів та систем, у тому числі на симуляційних манекенах. Таким чином, симуляційне навчання є необхідним напрямком у сучасному навчальному процесі [20].

Студенти повинні набути практичних навичок клінічної медицини в спеціальних центрах, обладнаних високотехнологічними тренажерами та комп’ютеризованими манекенами, що дозволяють моделювати клінічну ситуацію до застосування їх на реальних пацієнтах. Для забезпечення високої якості практичної підготовки також необхідне використання визначених педагогічних технологій, що забезпечують послідовність системи відпрацювання і вдосконалення практичних навичок та підготовки до виконання професійної діяльності на всіх етапах навчання студентів [21].

Досвід живого спілкування з реальними пацієнтами, можливість спостерігати за діями професіоналів, розвиток клінічного мислення - переваги традиційного класичного навчання біля ліжка хворого. Але воно має деякі недоліки: не всі студенти мають можливість самостійно виконати якусь дію або маніпуляцію; неможливість багаторазового їі повторення; в процесі навчання велика вірогідність порушення права пацієнта на якісне надання допомоги; не завжди існує можливість педагогічного контролю ступеня досягнення компетентності (виконання дій $з$ його обгрунтуванням) [22, 23]. Крім того, безпека пацієнта та його благополуччя представляють фундаментальну етичну проблему [22]. Для того щоб бути успішним лікарем, необхідно мати великий практичний досвід. Тому симуляційні ситуації створюються саме для того, щоб відпрацювати без ризику для пацієнта всі необхідні навики та виробити уміння [24, 25].

Симуляційне навчання дає можливість людям, які навчаються, виконати професійну діяльність відповідно до професійних стандартів і правил надання медичної допомоги в умовах, максимально набли- 
жених до реального виробничого середовища. За допомогою симуляційних методів відпрацьовуються практичні навики та вміння лікаря. Навик - багаторазове повторення, доведене до автоматизму, здатність виконувати певну дію, вміння - відпрацьований спосіб виконання складних дій, що забезпечується сукупністю знань і навичок.

Одним з актуальних розділів внутрішньої медицини є “Невідкладні стани”. Загрожуючі життю стани, за даними ВОО3, у 25 \% випадків закінчуються смертю, тобто в кожному четвертому випадку смерть стає умовно відверненою і виживання залежить від кваліфікації спеціаліста, що надає першу екстрену лікарську допомогу.

Диференційна діагностика та купування невідкладних станів представляють особливу складність для лікарів. Важливо розпізнати всі симптоми і своєчасно почати терапію, щоб запобігти погіршенню стану, зупинці дихання та серця. Саме тому правильна діагностика та профілактика ускладнень є основними моментами невідкладної допомоги.

3 метою вдосконалення підготовки лікарів та формування компетенцій у питаннях надання невідкладної допомоги одним з пріоритетних напрямків є необхідність розробки симуляційної практики. Використання симуляційних технологій при імітації різноманітних клінічних сценаріїв, відпрацювання технічних навичок окремих діагностичних ситуацій дозволяє досягти максимального ступеня засвоєння надання невідкладної допомоги в критичній ситуації.

На кафедрі внутрішньої медицини 3 ДЗ “ДМА MO3 України” для студентів 6 курсу запропоновано симуляційне тренування розпізнавання та надання допомоги при різних невідкладних станах. Симулятори - ознайомлені з клінічним сценарієм того чи іншого невідкладного стану спеціально підготовлені люди.

Людей, навчених зображувати пацієнтів, називали по-різному в різні роки. Так, у 1960-х роках їх назвали запрограмованими пацієнтами (programmed patients), пізніше 1970-х років - симульованими пацієнтами (simulated patients). При використанні для оцінки умінь студентів медичних вузів їх стали називати стандартизованими пацієнтами (standardized patients). Стандартизований пацієнт - це спеціально підготовлена людина, яка бере участь у навчанні та оцінці компетенцій учня. Цю термінологію приписують канадському психометристу Джеффрі Норману. Людей, що зображують батьків або родичів пацієнта або інших медичних працівників у клініч- ній задачі, які не є пацієнтами, називають стандартизованим учасником [26].

Стандартизований пацієнт, інсценуючи клінічний випадок, володіє повною інформацією про провідні скарги при тому або іншому стані, анамнезу хвороби та життя, описує дані об'єктивного дослідження. Крім того, студент обов’язково оцінює дані додаткових лабораторних, інструментальних методів дослідження, проведення яких вважає відповідним в тій чи іншій клінічній ситуації. За умови, що стандартизований пацієнт, який симулює невідкладний стан, непритомний, на допомогу приходить ще один симулятор - “супроводжувальна особа або родич”, який так само володіє інформацією клінічного сценарію. “Пацієнт” повинен суворо симулювати той чи інший клінічний сценарій строго в рамках “золотого стандарту”, записаного в його клінічному сценарії. Відступати за рамки клінічного сценарію стандартизований пацієнт не може.

Під час проведення заняття симуляційного тренінгу вчитель може дати стандартизовану оцінку вміння студентів проводити фізичне обстеження і збирати скарги та анамнез, а також комунікативним навичкам у спілкуванні з “хворими та членами його сім'і”, глибинам і діапазону знань, можливостями обгрунтувати та документувати дані, проводити диференційну діагностику та складати план лікування в будь-якій критичній ситуації. При використанні методики стандартизованого пацієнта на практичному занятті у студентів є також можливості, як зупинити або повторно почати бесіду або огляд, що сприяє кращому засвоєнню знань та вмінь.

Однією з найважливіших частин практичного заняття в умовах симуляційної техніки є дебрифінг [27]. Після закінчення роботи в навчальній кімнаті продовжується активне обговорення та детальний розбір наявних ситуацій. Викладачеві важливо при цьому зупинятися на позитивних діях з боку студентів, підкреслити, що невдачі, промахи, які вони допускали, добре їм запам'ятаються, і що після такого їх осмислення в реальній практиці цих помилок можна буде уникнути. На будь-яку запропоновану схему зі студентами розбираються питання етики та деонтології, крім того, йде розмова не тільки з кожним окремо з приводу його конкретних дій, але і з усією групою, яка також дає оцінку діям свого товариша.

Перелік невідкладних станів, які ми використовуємо на заняттях симуляційного тренування: гіпертензивний криз, гостра серцева недостатність, пароксизмальні порушення ритму, напади 
MEC, анафілактичний шок, переохолодження, тепловий удар, гостра дихальна недостатність, діабетична кома, судорожний синдром, гіповолемічний шок.

Саме симуляційні методики навчання дозволять не тільки навчитися на практиці застосовувати методи інтенсивної терапії при різних критичних станах на основі європейських протоколів та стандартів, але і за рахунок розроблених спеціальних прийомів довести їх виконання до досконалості. J. L. Hodgson та співавтори [28] повідомили, що студенти, впевнені в тому, що вони добре справляються з ситуаціями на стандартизованих пацієнтах, випробовують відчуття підвищеної власної ефективності. Як наслідок, підвищення упевненості у своїй компетенції та можливість практикуватися в симуляторах знижують ризик заподіяння можливої шкоди пацієнту, ймовірності неправильного вирішення проблем і забезпечують навчання вмінь, необхідних при роботі з реальними пацієнтами.

Цінність даної методики, на наш погляд, є очевидною: по-перше, студент має можливість розробити практичні навички, а в разі помилки виправити наявні недоліки. По-друге, студент вчиться працювати самостійно, один на один з пацієнтом, покладаючись тільки на свої сили та знання. По-третє, студент звикає працювати в умовах строго обмеженого часу (5 хв опробування, 5 хв огляду), дефіцит якого є однією з реалій трудових буднів лікаря будь-якої спеціальності, тим більше в критичній ситуації.

Таким чином, шляхом впровадження симуляційних тренінгів для студентів ми змогли вирішити такі завдання:

1) формування високого рівня практичних навичок проведення диференційного діагнозу та надання допомоги при невідкладних станах;

2) підготовка професійно-компетентного спеціаліста, здатного діагностувати та застосовувати в клінічній ситуації свої знання та практичні навики;

3) виявлення етіологічних факторів виникнення критичних ситуацій, основних та другорядних симптомів, характерних для різних невідкладних станів з оцінкою їх діагностичного значення;

4) створення алгоритму надання невідкладної допомоги;

5) контроль якості формування практичної професійної компетентності студентів.
Головним, на наш погляд, негативним моментом $€$ нав’ язування невідкладних станів. У своєму виборі ми спиралися на частоту виникнення тих чи інших критичних станів і вибирали ті, які найбільш часто зустрічаються у пацієнтів терапевтичного профілю. Крім того, симуляційне навчання не замінює навчання “біля ліжка хворого”. Саме реальний пацієнт, можливість зібрати у нього скарги, анамнез, знайти підхід до його родичів, завоювати довіру пацієнта - це головна і принципова відмінність реальної та імітаційної клінічної ситуації. Обидві технології в сучасному навчальному процесі повинні органічно доповнювати друг друга. Віртуальний симулятор не замінює традиційні форми навчання у вигляді лекцій, практичних занять, перегляду відео- та мультимедійних матеріалів. Однак, перш ніж допустити молодого спеціаліста до самостійного виконання різних маніпуляцій, йому необхідно розробити практичні навички та вміння на тренажері-симуляторі.

Висновки. Перевагами симуляційного навчання є:

1) реалістичне навчання без ризику для пацієнта;

2) тривалість і кількість повторень навчального процесу не обмежені;

3) відсутність стресу для студента;

4) формування пам’яті студентів;

5) об’єктивна оцінка дій студентів;

6) підвищення рівня компетентності студентів;

7) забезпечення інтеграції змісту навчального плану в практичну діяльність.

Вибір форм симуляційного навчання має бути спрямований на формування високого рівня клінічної компетентності у сфері діагностики та лікування невідкладних станів, яка повинна бути інтегрована з навиками спілкування. Це дозволить ефективно використовувати набуту клінічну компетентність у конкретній практичній діяльності лікаря. Використання освітніх програм на основі симуляційних технологій сприяє підвищенню професійності, компетенції медичних працівників, що позитивно відбивається на якості надання екстреної медичної допомоги.

Таким чином, ми пропонуємо розглянути симуляційні технології навчання студентів не тільки як складову частину клінічної підготовки, а більше того, як одного з механізмів, які запускають і формують клінічне мислення на високому та мотивованому рівні. 


\section{Список літератури}

1. Kohn L. T. To err is human: Building a safer health system / L. T. Kohn, J. M. Corrigan, M. S. Donaldson. Washington DC : National Academy Press, 1999. - 403 p.

2. Incidence of adverse events and negligence in hospitalized patients: Results of the Harvard Medical practice Study 1 / T. A. Brennan, L. L. Leape, N. M. Laird [et al.] // N. Engl. J. Med. - 1991. - Vol. 324. - P. 360-376.

3. Cost of adverse drug events in hospitalized patients. Adverse drug events prevention study group / D. W. Bates, N. Spell, D. J. Cullen [et al.] // JAMA. - 1997. - Vol. 277. P. 307-311.

4. Smith S. R. AMEE Guide No 14: Outcome-based education: Part 2- Planning, implementing, and evaluation of competency-based curriculum / S. R. Smith, R. Dollas // Med. Teach. - 1999. - Vol. 21. - P. 15-22.

5. Sičaja M. Medical students’ clinical skills do not match their teachers' expectations: Survey at Zagreb University School of Medicine, Croatia / M. Sičaja, D. Romić, Ž. Prka // Croat Med J. - 2006. - Vol. 47, No. 1. - P. 169-175.

6. Simulation and new learning technologies / S. B. Issenberg, M. S. Gordon, D. L. Gordon [et al.] // Med. Teach. - 2001. - Vol. 16. - P. 16-23.

7. Dent J. A. Current trends and future implications in the developing role of clinical skills centres / J. A. Dent // Med. Teach. - 2001. - Vol. 23. - P. 483-489.

8. Robertson B. Simulation-based crisis team training for multidisciplinary obstetric providers / B. Robertson, L. Schumacher, G. Gosman // Simul. Health. - 2009. Vol. 4, No. 2. - P. 77-83.

9. Cooper J. B. A brief history of the development of mannequin simulators for clinical education and training / J. B. Cooper, V. R. Taqueti // Qual. Saf. Health Care. 2004. - Vol. 13, No. 1. - P. 11-18.

10. Yaeger K. A. Making the move: From traditional neonatal education to simulation-based training / K. A. Yaeger, J. M. Arafeh // J. Perinat. Neonatal Nurs. - 2008. - Vol. 22, No. 2. - P. 154-158.

11. Sahu S. Simulation in resuscitation teaching and training, an evidence based practice review / S. Sahu, I. Lata // J. Emerg. Trauma Shock. - 2010. - Vol. 3, No. 4. P. 378-384.

12. Gordon J. A. Bringing good teaching cases "to life": A simulation-based medical education service / J. A. Gordon, N. E. Oriol, J. B. Cooper // Acad. Med. - 2004. - Vol. 79, No. 1. - P. 23-27.

13. Abdulmohsen Al-Elq H. Simulation-based medical teaching and learning / H. Al-Elq Abdulmohsen // J. Family Community Med. - 2010. - Vol. 17, No. 1. - P. 35-40.

14. Issenberg S. B. Feature and uses of high-fidelity medical simulations that lead to effective learning: A BEME systematic review / S. B. Issenberg, W. C. McGaghie, E. R. Petrusa // Med. Teach. - 2005. - Vol. 27, No. 1. - P. 10-28.
15. Ypinazar V. A. Clinical simulators: Applications and implication for rural medical education / V. A. Ypinazar, S. A. Margolis // Rural Remote Health. - 2006. - Vol. 6, No. 2. - P. 527-538.

16. Cherry R. A. Current concepts in simulation-based trauma education / R. A. Cherry, J. Ali // J. Trauma. - 2008. Vol. 65, No. 5. - P. 1186-1193.

17. Flangan B. Making patient safety the focus: Crisis resorce management in the undergraduate curriculum / B. Flangan, D. Nestel, M. Joseph // Med. Edu. - 2004. Vol. 38, No. 1. - P. 56-66.

18. Ziv A. Simulation Based Medical Education: An opportunity to learn from errors / A. Ziv, S. Ben-David, M. Ziv // Med. Teach. - 2005. - Vol. 27, No. 3. - P. 193-199.

19. Vozenilek J. See one, do one, teach one: Advanced technology in medical education / J. Vozenilek, J. S. Huff // Acad. Emerg. Med. - 2004. - Vol. 11, No. 1. - P. 1149-1154. 20. The utility of simulation in medical education: what is the evidence? / Y. Okuda, E. O. Bryson, S. Jr. DeMaria [et al.] // Mt. Sinai J. Med. - 2009. - Vol. 76, No. 4. P. 330-343.

21. Maran N. J. Low-to high-fidelity simulation - a continuum of medical education? / N. J. Maran, R. J. Glavin // Med. Edu. - 2003. - Vol. 37, No. 1. - P. 22-28.

22. Teaching residents the two-challenge rule: A simulation-based approach to improve education and patient safety / M. C. Pian-Smith, R. Simon, R. D. Minehart [et al.] // Simul. Healthc. - 2009. - Vol. 4, No. 2. - P. 84-91.

23. Scalese R. J. Simulation technology for skills training and competency assessment in medical education / R. J. Scalese, V. T. Obeso, S. B. Issenberg // J. Gen. Intern. Med. 2008. - Vol. 23, No. 1. - P. 46-49.

24. Margan P. J. Simulation technology in training students, residents and faculty / P. J. Margan, D. Cleave-Hogg // Curr. Opin. Anaesthesiol. - 2005. - Vol. 18. - P. 199-203.

25. Barrows H. "An overview of the uses of standardized patients for teaching and evaluating clinical skills”/ H. Barrows // Academic Medicine. - 1993. - Vol. 68, No. 6. P. 443-453.

26. Wallace P. Coaching standardized patients: For use in the assessment of clinical competence / P. Wallace. - Cambridge, 2006. - P. 207.

27. Debriefing as formative assessment: Closing performance gaps in medical education / J. W. Rudolph, R. Simon, D. B. Raemer, W. J. Eppich // Acad. Emerg. Med. - 2008. Vol. 15, No. 11. - P. 1010-1006.

28. Hodgson J. L. Use of simulated clients in marriage and family therapy education / J. L. Hodgson, A. L. Lamson, E. B. Feldhousen // JMFT. - 2007. - Vol 33, No. 1. - P. 3550. doi: 10.1111/j.1752-0606.2007.00003.2007. 


\section{References}

1. Kohn, L.T., Corrigan, J.M., \& Donaldson, M.S. (1999). To err is human: Building a safer health system. Washington DC: National Academy Press.

2. Brennan, T.A., Leape, L.L., Laird, N.M., Hebert, L., Localio, A.R., \& Lawthers, A.G. (1991). Incidence of adverse events and negligence in hospitalized patients: Results of the Harvard Medical practice Study 1. N. Engl. J. Med., 324, 360-376.

3. Bates, D.W., Spell, N., Cullen, D.J., Burdick, E., Laird, N., \& Petersen, L.A. (1997). Cost of adverse drug events in hospitalized patients.Adverse drug events prevention study group. JAMA, 277, 307-311.

4. Smith, S.R., \& Dollas, R. (1999). AMEE Guide No 14: Outcome-based education: Part 2- Planning, implementing, and evaluation of competency-based curriculum. Med. Teach., 21, 15-22.

5. Sičaja, M., Romić, D., \& Prka, Z. (2006). Medical students' clinical skills do not match their teachers' expectations: Survey at Zagreb University School of Medicine, Croatia. Croat. Med. J., 47 (1), 169-175.

6. Issenberg, S.B., Gordon, M.S., Gordon, D.L., Safford, R.E., \& Hart, I.R. (2001). Simulation and new learning technologies. Med Teach., 16, 16-23. DOI:10:1080/01421590020007324.

7. Dent, J.A. (2001). Current trends and future implications in the developing role of clinical skills centres. Med. Teach., 23, 483-489. DOI:10.1080/01421590120075724.

8. Robertson, B., Schumacher, L., Gosman, G., Kanfer, R., Kelley, M., \& DeVita, M. (2009). Simulationbased crisis team training for multidisciplinary obstetric providers. Simul. Health, 4 (2), 77-83. doi: 10.1097/ SIH.0b013e31819171cd.

9. Cooper, J.B., \& Taqueti, V.R. (2004). A brief history of the development of mannequin simulators for clinical education and training. Qual. Saf. Health Care, 13 (1), 11-18. doi: 10.1136/qshc.2004.009886.

10. Yaeger, K.A., \& Arafeh, J.M. (2008). Making the move: From traditional neonatal education to simulationbased training. J. Perinat. Neonatal Nurs., 22 (2),154-158. doi:10.1097/01.JPN.0000319103.28217.26.

11. Sahu, S., \& Lata, I. (2010). Simulation in resuscitation teaching and training, an evidence based practice review. J. Emerg. Trauma Shock, 3 (4), 378-384. doi: 10.4103/09742700.70758.

12. Gordon, J.A., Oriol, N.E., \& Cooper, J.B. (2004). Bringing good teaching cases "to life": A simulation-based medical education service. Acad. Med., 79 (1), 23-27.

13. Abdulmohsen, H. Al-Elq (2010). Simulation-based medical teaching and learning. J. Family Community Med., 17 (1), 35-40. doi: 10.4103/1319-1683.68787.

14. Issenberg, S.B., McGaghie, W.C., Petrusa, E.R., Lee Gordon, D., \& Scalese, R.J. (2005). Feature and uses of highfidelity medical simulations that lead to effective learning:
A BEME systematic review. Med. Teach., 27 (1), 10-28. DOI:10.1080/01421590500046924.

15. Ypinazar, V.A., \& Margolis, S.A. (2006). Clinical simulators: Applications and implication for rural medical education. Rural Remote Health, 6 (2), 527-538.

16. Cherry, R.A., \& Ali, J. (2008). Current concepts in simulation-based trauma education. J. Trauma, 65 (5), 11861193 doi: 10.1097/TA.0b013e318170a75e.

17. Flangan, B., Nestel, D., \& Joseph, M. (2004). Making patient safety the focus: Crisis resorce management in the undergraduate curriculum. Med. Edu., 38(1), 56-66.

18. Ziv, A., Ben-David, S., \& Ziv, M. (2005). Simulation Based Medical Education: An opportunity to learn from errors. Med. Teach., 27 (3), 193-199. DOI: $10.1080 / 01421590500126718$.

19. Vozenilek, J., Huff, J.S., Reznek, M., \& Gordon, J.A. (2004). See one, do one, teach one: Advanced technology in medical education. Acad. Emerg. Med., 11 (1), 1149-1154. DOI: $10.1197 /$ j.aem.2004.08.003.

20. Okuda, Y., Bryson, E.O., DeMaria, S. Jr., Jacobson, L., Quinones, J., Shen, B., \& Levine, A.I. (2009). The utility of simulation in medical education: what is the evidence? Mt. Sinai J. Med., 76 (4), 330-343. doi: 10.1002/msj.20127.

21. Maran, N.J., \& Glavin, R.J. (2003). Low-to high-fidelity simulation - a continuum of medical education? Med. Edu., 37, 22-28.

22. Pian-Smith, M.C., Simon, R., Minehart, R.D., Podraza, M., Rudolph, J., \& Walzer, T. (2009). Teaching residents the two-challenge rule: A simulation-based approach to improve education and patient safety. Simul. Healthc., 4 (2), 84-91. doi: 10.1097/SIH.0b013e31818cffd3.

23. Scalese, R.J., Obeso, V.T., \& Issenberg, S.B. (2008). Simulation technology for skills training and competency assessment in medical education. J. Gen. Intern. Med., 23 (1), 46-49. doi: 10.1007/s11606-007-0283-4.

24. Margan, P.J., \& Cleave-Hogg, D. (2005). Simulation technology in training students, residents and faculty. Curr. Opin. Anaesthesiol., 18, 199-203.

25. Barrows, H. (1993). An overview of the uses of standardized patients for teaching and evaluating clinical skills. Academic Medicine., 68 (6), 443-453.

26. Wallace, P. (2006). Coaching Standardized Patients: For Use in the Assessment of Clinical Competence. Cambridge.

27. Rudolph, J.W., Simon, R., Raemer, D.B., \& Eppich WJ. (2008). Debriefing as formative assessment: Closing performance gaps in medical education. Acad. Emerg. Med., 15(11), 1010-1016. doi: 10.1111/j.1553-2712.2008.00248.x. 28. Hodgson, J.L., Lamson, A.L., \& Feldhousen, E.B. (2007). Use of simulated clients in marriage and family therapy education. JMFT., 33, 35-50. https://doi.org/10.1111/ j.1752-0606.2007.00003.x. 